\title{
A new transthyretin variant (Ser 24) associated with familial amyloid polyneuropathy
}

\author{
Tomoyuki Uemichi, Morie A Gertz, Merrill D Benson
}

\begin{abstract}
An American kindred with systemic amyloidosis presenting with carpal tunnel syndrome, peripheral neuropathy, and cardiomyopathy is reported. The transthyretin gene of a patient was analysed by direct DNA sequencing and both cytosine and thymine were present at the first base of codon 24. This new point mutation in exon 2 results in the amino acid substitution of serine for proline in the A-B loop of the transthyretin molecule. DNA testing for this mutant allele by restriction fragment length polymorphism analysis based on the polymerase chain reaction is described.
\end{abstract}

(f Med Genet 1995;32:279-281)

Familial amyloid polyneuropathy (FAP) is a genetic disorder with late onset autosomal dominant inheritance. It is characterised by extracellular deposition of eosinophilic proteinaceous fibrillar substance known as amyloid. ${ }^{1}$ It is a systemic disease and causes various kinds of clinical symptoms including autonomic dysfunction, sensorimotor neuropathy, carpal tunnel syndrome (CTS), vitreous opacification, cardiomyopathy, renal dysfunction, and gastrointestinal tract disorder. ${ }^{2}$ It was originally described by Andrade in 1952 as familial atypical generalised amyloidosis in a large Portuguese kindred, ${ }^{3}$ and has been reported in many countries all over the world. In 1983 the first variant transthyretin (TTR), which had an amino acid substitution of methionine for valine at position 30 , was found to be re- sponsible for the disease. ${ }^{4}$ Since then various mutations in transthyretin have been shown to be associated with the disease.

In this study we report a kindred with systemic amyloidosis manifested as CTS, polyneuropathy, and cardiomyopathy and a new mutation in exon 2 of the TTR gene which leads to an amino acid substitution of serine for proline at position 24 of mature TTR.

\section{Case reports}

The proband (II 6 , fig 1), a 67 year old white man who was born in Kentucky, presented with 18 months of uncontrolled diarrhoea associated with a $10 \mathrm{~kg}$ weight loss. He had had bilateral carpal tunnel surgery 15 years earlier, was impotent since the age of 59, and had paraesthesia in both lower extremities to the mid-calf of two years' duration. There was a history of cardiac irregularity and his echocardiogram showed evidence of amyloid cardiomyopathy. He died from cardiac failure at the age of 69 .

His family history is notable. Three of his five sibs (II·2, II 4 , II $\cdot 5)$ died of cardiac disease. One of them (II.2) died at the age of 72 and necropsy showed advanced cardiac amyloidosis. Two of his three sons (III.5, III.6) are also reported to have amyloidosis. Another brother of the proband (II.5) was documented to have bilateral CTS at the time of his death at the age of 73 . His 52 year old daughter (III-16) has bilateral CTS.

\section{Materials and methods}

Blood samples were obtained from three affected members (II·6, III 5 , and III 6 ) and six at
Departments of Medicine and Medical and Molecular Genetics, Indiana University School of Medicine and Veterans Affairs Medical Center, Indianapolis, Indiana 46202, USA $\mathrm{T}$ Uemichi M D Benson

Hematology and Internal Medicine, Mayo Clinic. Rochester, Minnesota 55905, USA

M A Gertz

Correspondence to: Dr Benson.

Received 24 August 1994 Revised version accepted for publication 28 November 1994

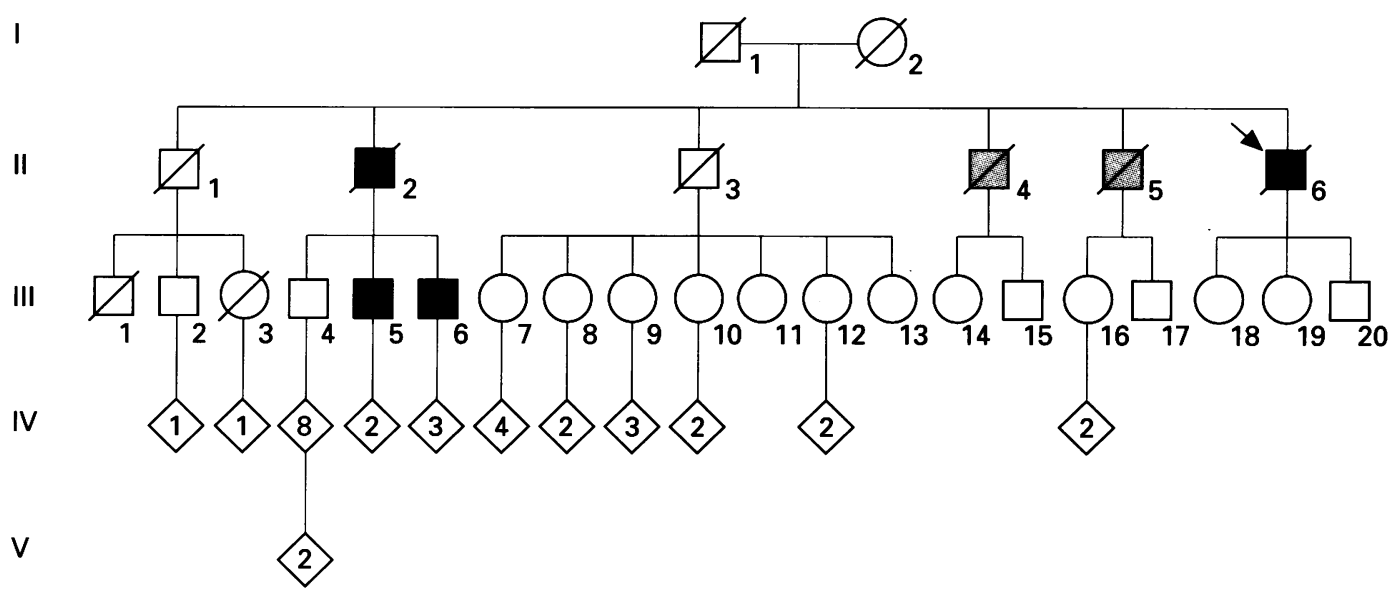

Figure 1 Pedigree of the kindred. Solid symbols indicate people with confirmed amyloidosis and shadowed symbols indicate those with possible amyloidosis. The arrow denotes the proband. Diamonds indicate multiple sibs. 

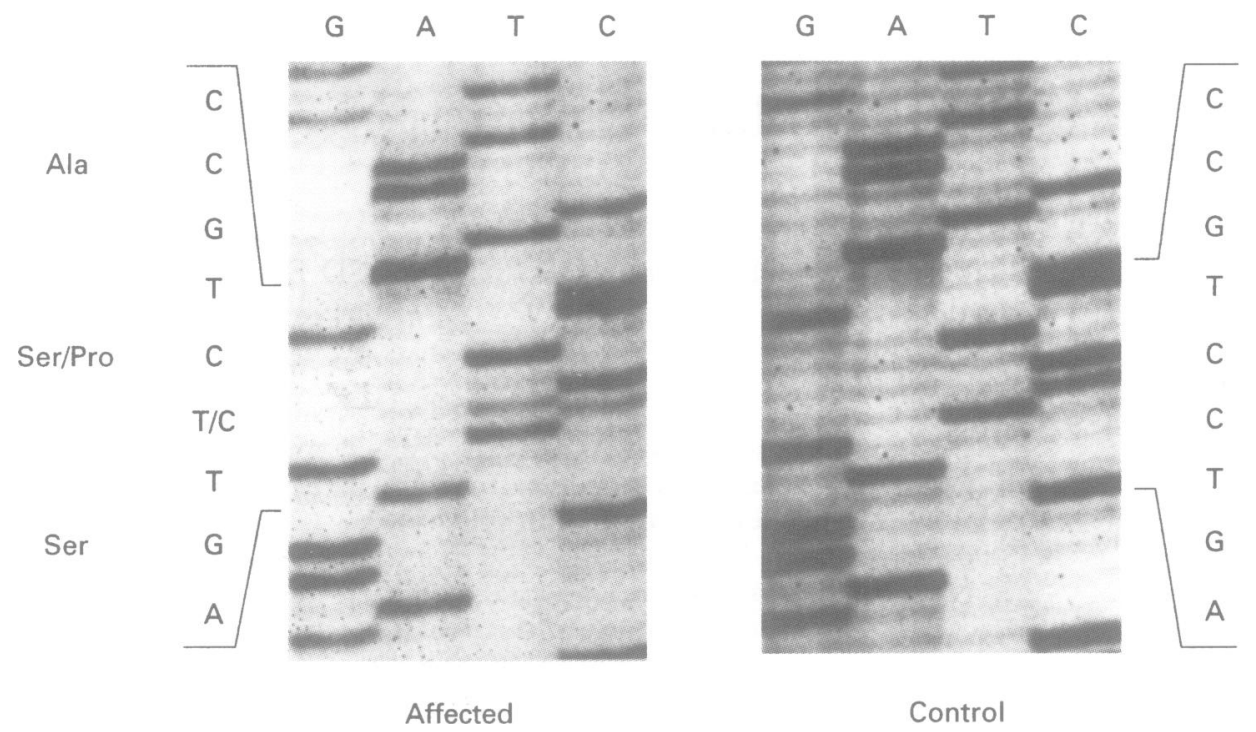

Figure 2 Autoradiogram of direct DNA sequencing of exon 2 of the TTR gene. Both cytosine and thymine are present at the first base of codon 24 of the TTR gene.

risk members of this kindred. Total genomic DNA was isolated from peripheral blood cells using a conventional method. ${ }^{5}$

DIRECT DNA SEQUENCE ANALYSIS

The TTR gene exons 2, 3, and 4 of the proband were examined by the direct DNA sequence described previously. ${ }^{6}$

\section{RESTRICTION FRAGMENT LENGTH}

POLYMORPHISM (RFLP) ANALYSIS

Since no DNA restriction endonuclease was available which could distinguish the mutant from the normal allele, DNA from family members was examined by PCR induced mutation restriction analysis (PCR-IMRA). A new primer arranged to give a recognition site of $E c o \mathrm{RI}$ in the mutant gene (5'-TCTAGATGCTGTCCGAGGGAAT-3') was synthesised. This primer has two mismatched bases: an $A$ instead of a normal $G$ at the second position from the $3^{\prime}$ end and a $G$ instead of a $\mathrm{C}$ at the fourth position. This creates an $E c o$ RI site (GAATTC) only when the TTR gene has a $\mathrm{T}$ at position $1080 .^{7} \mathrm{PCR}$ was performed

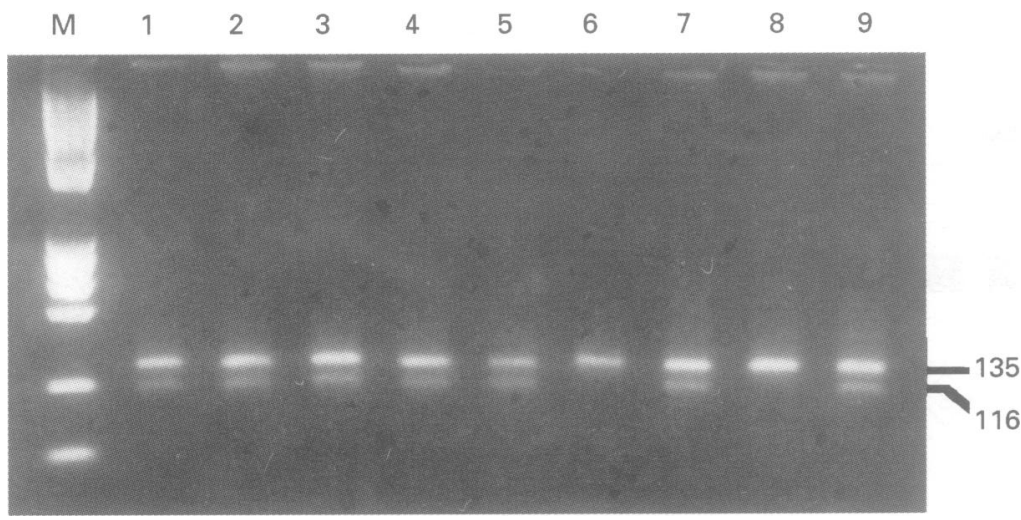

Figure 3 Ethidium bromide stained agarose gel showing the PCR-IMRA of this kindred. Lanes 1-3, affected subjects; lanes 4-9, subjects at risk in this kindred. Lane $M, \emptyset X 174$ HaeIII digest DNA size marker. The figures on the right denote the sizes of the bands in base pairs. with this new primer and E2LP2 primer (5'AGATCTGCAGAAGTCCTGTGGGAGGGTTCT-3'). PCR conditions included 35 cycles of $94^{\circ} \mathrm{C}$ for one minute, $50^{\circ} \mathrm{C}$ for one minute, and $72^{\circ} \mathrm{C}$ for one minute. Ten units of restriction endonuclease EcoRI (New England Biolabs Inc, Beverly, MA) was directly added to $10 \mu \mathrm{l}$ of PCR products and incubated at $37^{\circ} \mathrm{C}$ for three hours. Samples were electrophoresed through 3\% Nusieve GTG agarose gel, stained with ethidium bromide, and photographed under UV light.

\section{Results}

Direct sequencing of the exon 2 PCR product from the proband's DNA showed both cytosine and thymine at position 1080 of the TTR gene (fig 2). Thus the proband was heterozygous with both a normal CCT (proline) and a variant TCT (serine) codon corresponding to amino acid position 24 of mature TTR. DNA sequences for exons 3 and 4 were identical to those of the normal TTR gene.

RFLP analysis showed that four of six subjects at risk as well as all three affected subjects had a digestion band of $116 \mathrm{bp}$ in addition to the normal band of $135 \mathrm{bp}$ (fig 3), proving that they were heterozygous for the TTR Ser 24 gene.

\section{Discussion}

Since variant forms of TTR are the most common cause of CTS with autosomal dominant inheritance, only the TTR gene was examined for mutations in this kindred. Although amyloid laden tissues were not available to prove deposition of variant TTR, the presence of the mutant gene in all affected members of this kindred strongly suggests that the TTR Ser 24 is responsible for the disease.

It is known that each TTR mutation has a relatively specific clinical manifestation and that kindreds that are not related to each other but share a common mutation have similar symptomatology. The TTR Ser 24 kindred described here has CTS as well as peripheral 
neuropathy, cardiomyopathy, and dysfunction of the digestive system. While these manifestations are seen in most kindreds with TTR mutations, CTS is described in fewer than one-third of FAP kindreds and has been used to classify kindreds into a subtype of FAP, FAP type II. The first hereditary amyloidosis kindred with CTS was reported by Rukavina et $a l^{8}$ in 1956. Amyloidosis in this kindred, which was also called Indiana/Swiss type, was found to be associated with a variant TTR Ser 84 by Dwulet and Benson ${ }^{9}$ in 1986 . The clinical features of the Ser 84 kindred are similar to those of the kindred described here except for the presence of vitreous opacification and the relatively early onset age. Subsequently several TTR mutations were found to cause FAP and CTS. Among them, kindreds with His 58 and Ala 60 mutations show clinical features similar to the kindred with Ser 24 including the absence of vitreous opacification, relatively late onset, and slow progression of the disease. ${ }^{610}$

Over 40 TTR mutations have been identified in amyloidosis patients. ${ }^{2}$ It is notable that no other amyloidogenic mutation has been found in the $\mathrm{N}$-terminal portion (1-29) except for Arg 10 which is unique for replacing the sole cysteine. ${ }^{11}$ The remainder of the mutations are distributed over amino acid 30-122 of the 127 amino acid protein. Ser 24, which is located on the A-B loop, is the first mutation in this region and may suggest that amino acid substitution at any part of TTR can result in amyloid fibril formation. ${ }^{12}$
This work was supported by the Veterans Affairs Medical Research (MRIS 583-0888), and grants from RR-00750 (GCRC), United States Public Health Service, NIDDK-42111 AG 10608, National Institute of Arthritis Metabolism and Digestive Diseases (AM20582), The Arthritis Foundation, and The Marion E Jacobson Fund.

1 Husby G. Nomenclature and classification of amyloid and amyloidoses. F Intern Med 1992;232:511-12.

2 Benson MD. Amyloidosis. In: Scriver CR, Beaudet AL, Sly WS, Valle DV, eds. The metabolic basis of inherited disease. 7th ed. New York: McGraw-Hill, 1995: 4159-91.

3 Andrade C. A peculiar form of peripheral neuropathy. Familial atypical generalized amyloidosis with special in-
indrade $C$. A peculiar form of peripheral neuropathy. Familial atypical generalized amyloidosis with special in
volvement of the peripheral nerves. Brain 1952;75:408-27.

4 Dwulet FE, Benson MD. Polymorphism of human plasma thyroxine binding prealbumin. Biochem Biophys Res Commun 1983;114:657-62.

5 Madisen L, Hoar DI, Holroyd CD, Crisp M, Hodes ME. DNA banking: the effects of storage of blood and isolated DNA on the integrity of DNA. Am $\mathcal{F}$ Med Genet 1987;27: 379-90.

6 Nichols WC, Liepnieks JJ, McKusick VA, Benson MD. Direct sequencing of the gene for Maryland/German familial amyloidotic polyneuropathy type II and genotyping by allele-specific enzymatic amplification. Genomics 1989 ; 5:535-40.

7 Tsuzuki T, Mita S, Maeda S, Araki S, Shimada K. Structure of human prealbumin gene. $\mathcal{F}$ Biol Chem $1985 ; 260$ :122247.

8 Rukavina JG, Block WD, Jackson CE, Falls HF, Carey JH, Curtis AC. Primary systemic amyloidosis: a review and an experimental, genetic, and clinical study of 29 cases an experimental, genetic, and clinical study of 29 cases
with particular emphais on the familial form. Medicine with particular emphais on the
(Baltimore) 1956;35:239-344.

9 Dwulet FE, Benson MD. Characterization of a transthyretin (prealbumin) variant associated with familial amyloidotic polyneuropathy type II (Indiana/Swiss). F Clin Invest 1986; 78:880-6.

10 Wallace MR, Dwulet FE, Conneally PM, Benson MD. Biochemical and molecular genetic characterization of a new variant prealbumin associated with hereditary amyloidosis. $\mathcal{F}$ Clin Invest 1986;78:6-12.

11 Uemichi T, Murrell JR, Zeldenrust S, Benson MD. A new mutant transthyretin (Arg 10) associated with familial amyloid polyneuropathy. $\mathcal{f}$ Med Genet 1992;29:888-91.

12 Blake CCF, Geisow MJ. Oatley SJ, Rerat B, Rerat C. Structure of prealbumin: secondary, tertiary and quaternary interactions determined by Fourier refinement at 1.8 A. F Mol Biol 1978;121:339-56. 